University of Nebraska - Lincoln

DigitalCommons@University of Nebraska - Lincoln

MANTER: Journal of Parasite Biodiversity

Parasitology, Harold W. Manter Laboratory of

9-12-2016

\title{
Population Characteristics of Human-Commensal Rodents Present in Households from Mérida, Yucatán, México
}

\author{
Jesús Alonso Panti-May \\ Universidad Autónoma de Yucatán, panti.alonso@gmail.com \\ Silvia F. Hernández-Betancourt \\ Universidad Autónoma de Yucatán \\ Marco A. Torres-Castro \\ Universidad Autónoma de Yucatán \\ Carlos Machaín-Williams \\ Universidad Autónoma de Yucatán \\ Nohemi Cigarroa-Toledo \\ Universidad Autónoma de Yucatán
}

See next page for additional authors

Follow this and additional works at: https://digitalcommons.unl.edu/manter

Part of the Biodiversity Commons, Other Animal Sciences Commons, Parasitology Commons, Population Biology Commons, and the Zoology Commons

Panti-May, Jesús Alonso; Hernández-Betancourt, Silvia F.; Torres-Castro, Marco A.; Machaín-Williams, Carlos; Cigarroa-Toledo, Nohemi; Sodá, Lorenzo; López-Manzanero, Gabriela; Meza-Sulú, Josué R.; and Vidal-Martínez, Victor M., "Population Characteristics of Human-Commensal Rodents Present in Households from Mérida, Yucatán, México" (2016). MANTER: Journal of Parasite Biodiversity. 5. https://digitalcommons.unl.edu/manter/5

This Article is brought to you for free and open access by the Parasitology, Harold W. Manter Laboratory of at DigitalCommons@University of Nebraska - Lincoln. It has been accepted for inclusion in MANTER: Journal of Parasite Biodiversity by an authorized administrator of DigitalCommons@University of Nebraska - Lincoln. 


\section{Authors}

Jesús Alonso Panti-May, Silvia F. Hernández-Betancourt, Marco A. Torres-Castro, Carlos MachaínWilliams, Nohemi Cigarroa-Toledo, Lorenzo Sodá, Gabriela López-Manzanero, Josué R. Meza-Sulú, and Victor M. Vidal-Martínez 
MANTER: Journal of Parasite Diversity (ISSN 2470-8224)

Occasional Papers, Number 5, September 12, 2016. doi:10.13014/K2VD6WCX

Copyright @ 2016 Panti-May, Hernández-Betancourt, Torres-Castro, Machaín-Williams,

MANTER: Journal

Cigarroa-Toledo, Sodá, López-Manzanero, Meza-Sulú, and Vidal-Martínez.

This paper was part of a symposium on mammal parasite biodiversity, "CLM20 - Zoonosis y mamíferos Neotropicales" [Zoonoses and Neotropical Mammals], presented at III Congreso Latinoamericano de Mastozoología, Bogotá D.C., Colombia, 1 al 5 de diciembre del 2015.

\title{
Population Characteristics of Human-Commensal Rodents Present in Households from Mérida, Yucatán, México
}

\author{
Jesús Alonso Panti-May, ${ }^{1}$ Silvia F. Hernández-Betancourt, ${ }^{2}$ Marco A. Torres-Castro, ${ }^{3}$ \\ Carlos Machaín-Williams, ${ }^{4}$ Nohemi Cigarroa-Toledo, ${ }^{4}$ Lorenzo Sodá, ${ }^{2}$ \\ Gabriela López-Manzanero, ${ }^{2}$ Josué R. Meza-Sulú, ${ }^{2}$ and Victor M. Vidal-Martínez ${ }^{5}$ \\ 1 Doctorado en Ciencias Agropecuarias, Facultad de Medicina Veterinaria y Zootecnia, Universidad \\ Autónoma de Yucatán, C.P. 97135, Mérida, Yucatán, México \\ 2 Departamento de Zoología, Facultad de Medicina Veterinaria y Zootecnia, Universidad Autónoma de \\ Yucatán, C.P. 97135, Mérida, Yucatán, México \\ 3 Laboratorio de Enfermedades Emergentes y Reemergentes, Centro de Investigaciones Regionales "Dr. \\ Hideyo Noguchi," Universidad Autónoma de Yucatán, C.P. 97000, Mérida, Yucatán, México \\ 4 Laboratorio de Arbovirología, Centro de Investigaciones Regionales "Dr. Hideyo Noguchi," Universidad \\ Autónoma de Yucatán, C.P. 97225, Mérida, Yucatán, México \\ 5 Departamento de Recursos del Mar, Centro de Investigación y de Estudios Avanzados del Instituto \\ Politécnico Nacional, Unidad Mérida, C.P. 97310, Mérida, Yucatán, México
}

Corresponding author - J. A. Panti-May, email panti.alonso@gmail.com

\begin{abstract}
Anthropocommensal rodents live in close proximity to humans in many habitats around the world. They are a threat to public health because of the pathogens they carry. Recent studies in Mérida, Yucatán, México, have shown that commensal rodents harbor potential zoonotic pathogens such as bacteria, helminths, and viruses. In this study, we describe reproductive and demographic parameters of house mice and black rats present in households from Mérida, Yucatán, México, a municipality located in a tropical region in southern México. Rodents were trapped in 142 households within the municipality of Mérida from 2011 to 2014. A total of 832 rodents were trapped, constituting 556 (66.8\%) house mice (Mus musculus) and 276 (33.2\%) black rats (Rattus rattus). The sex ratio in mice was different than parity, while in rats it was $1: 1$. Mice in the weight class $8.1-12$ $\mathrm{g}$ were most abundant in both females (52.9\%) and males (57.2\%). On the other hand, rats weighing $\leq 40 \mathrm{~g}$ ( $25 \%$ of females and $28.6 \%$ of males) were most abundant. The percentage of pregnancy in mice was $46.7 \%$, whereas in rats it was $21.3 \%$. The mean number of embryos was 4.7 and 5.8 in mice and rats, respectively. This study provides relevant demographic information on the ecology of commensal rodents from a tropical region of Latin America. We consider that our findings could be useful as a first step toward understanding the ecological behavior of rodent populations in tropical regions.
\end{abstract}

Keywords: Mus musculus, Rattus rattus, ecology, reservoir host, Mexico, tropical region

\section{Introduction}

Anthropocommensal or synanthropic (hereafter "commensal") rodents live in close proximity to humans. The most important commensal species are the house mouse (Mus musculus Linnaeus, 1758), the Norway or brown rat (Rattus norvegicus [Berkenhout, 1769]), and the black or roof rat (R. rattus [Linnaeus, 1758]). In many parts of the world, 
they are introduced species that show great adaptability to human-altered environments (Vadell et al., 2014). In urban and rural areas, commensal rodents abound in habitats where accumulated human garbage and favorable areas to build nests are plentiful. In residential areas, rodents are abundant in households with factors such as structural deficiencies, the presence of pets or livestock, lack of sanitation, and/or proximity to vacant lots (Langton et al., 2001; de Masi et al., 2009).

The house mouse and black rat are two commensal species that cause damage to native flora and fauna, economic losses to industries and households, and a threat to public health because of the pathogens they carry (Clapperton, 2006; Battersby et al., 2008). In relation to public health, recent studies in Mérida, Yucatán, México have reported potential zoonotic pathogens such as Leptospira spp. (TorresCastro et al., 2014), helminths (Panti-May et al., 2015), and flavivirus (Cigarroa-Toledo et al., 2016) in commensal rodents. However, studies on rodent populations are scarce in México and especially in tropical regions of Latin America compared to the vast information available from temperate populations. Moreover, like other rodent species that inhabit both tropical and temperate regions, population characteristics such as juvenile percentage, pregnancy rate, and weight can contrast from data described in temperate habitats (Porter et al., 2015). Ecological studies are critical to determine the dynamics of pathogen transmission within rodent populations, the risk of transmission to humans, and areas at high risk of transmission. The objective of this study was to describe reproductive and demographic parameters of commensal house mice and black rats present in households from Mérida, Yucatán, México, a municipality located in a tropical region in southern México.

\section{Methods}

This study was carried out in Mérida, the most populous municipality of Yucatán, México, with more than 830,732 inhabitants (Instituto Nacional de Estadística y Geografía, 2010). The regional climate is warm and subhumid, with an average annual temperature of $26^{\circ} \mathrm{C}$ and an average annual rainfall of $1100 \mathrm{~mm}$ (Instituto Nacional de Estadística y Geografía, 2015).

Intensive rodent trapping was carried out in 109 households of low socioeconomic status from 3 localities of the south of Mérida during a six-month period: 32 households in San José Tecoh and 34 households in Plan de Ayala Sur from May to October 2013, and 43 households in Molas from November 2013 to April 2014. Additionally, data from nonintensive trapping from November 2011 to November 2013 in 33 households within the Mérida city were included. In each household, 6-8 Sherman traps $(8 \times 9 \times 23$ cm; HB Sherman Traps, Inc., Tallahassee, Florida, USA) were set for three consecutive nights. Traps were baited with a mixture of oatmeal and vanilla essence and were distributed in the house and backyard close to signs of rodent activity or potential sources of food and/or harborage.

Field and laboratory rodent procedures were carried out following the guidelines of the American Society of Mammalogists for the use of wild mammals in research (Sikes et al., 2011), the guidelines of the American Veterinary Medical Association for the euthanasia of animals (Leary et al., 2013), and national specifications (SAGARPA NOM-062ZOO-1999). The rodent capture operation was conducted under license from the Mexican Ministry of Environment (SGPA/DGVS/02528/13).

After euthanasia, the species, sex, weight, and site of capture were recorded. Females were classified as mature if the vagina was open or if the specimen was pregnant (by visible embryos) or had evidence of lactation (by the presence of milk); males were so classified if they had scrotal testicles.

To determine whether the sex ratio varied from 1:1, a chi-square test with the Yates correction was used (Zar, 1996). Welch's two-sample t-test was used to compare the weight between sexes. Additionally, the weight of each rodent was classified in weight classes (mice in one of seven 4-g classes and rats in one of seven $20-\mathrm{g}$ classes) to determine whether the cumulative proportion of each class differed between sexes using the two-sample KolmogorovSmirnov test (Sheskin, 2004).

\section{Results}

A total of 832 commensal rodents were trapped, comprising 556 (66.8\%) house mice (Mus musculus) and 276 (33.2\%) black rats (Rattus rattus). Inside dwellings, 51.9\% (319/615) of rodents were trapped in areas such as the kitchen (44.7\%), storage for domestic appliances (18.8\%), and bedrooms (14.1\%). In backyards, 48.1\% (296/615) of rodents were frequently trapped next to henhouses (46.7\%); in areas with vegetative coverage such as weeds, herbs, or vegetable gardens (11.4\%); and alongside walls or fences (10.9\%).

Two hundred forty-five mice were females and 311 males, significantly different from parity $\left(\chi^{2}=7.83, P<\right.$ 0.01 ). The mean weight of nonpregnant females ( $n=189$ ) of $10.7 \mathrm{~g}$ (SE $=0.2 \mathrm{~g}$ ) was not significantly different from the $10.8 \mathrm{~g}$ (SE $=0.2 \mathrm{~g})$ of males $(t=-0.17, P=0.86)$. The mean weight of pregnant females was $14.1 \mathrm{~g}$ (SE $=0.4$ ). Mice in the weight class $8.1-12 \mathrm{~g}$ were most abundant in both nonpregnant females (52.9\%) and males (57.2\%). The distribution of weight classes was not different between sexes $(D=0.04, P=0.99$; Figure 1$)$. Maturity was recorded 


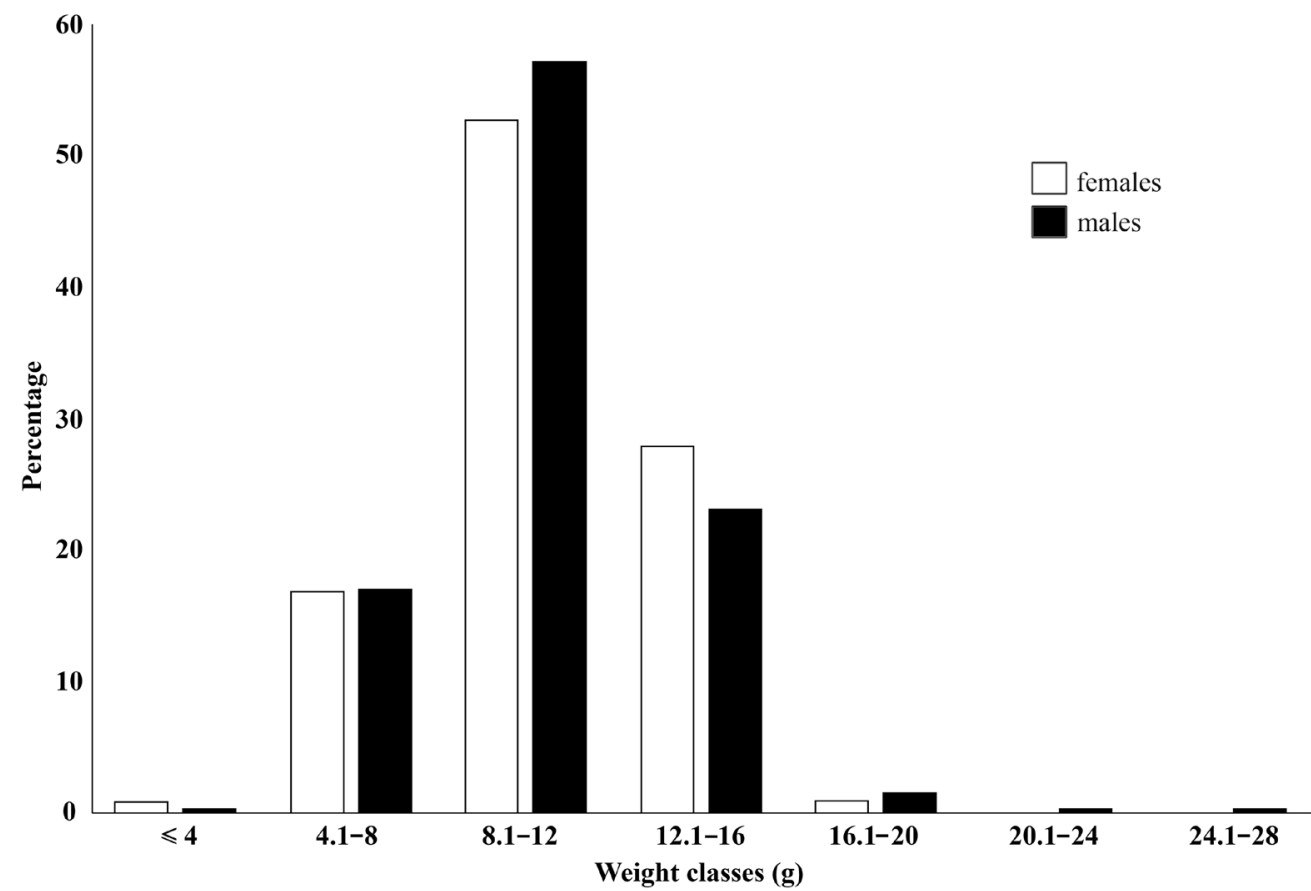

Figure 1. Comparison of weight classes for nonpregnant female $(n=189)$ and male $(n=311)$ house mice (Mus musculus) from Mérida, Yucatán, México. White bars represent females and black bars males.

in $77.6 \%(232 / 299)$ of males and $47.8 \%(120 / 241)$ of females. Of mature females (120), 56 (46.7\%) were pregnant and 23 (19.2\%) lactating. The mean number of embryos per female was 4.7 (range $=2-9$; Figure 2). All pregnant or lactating females weighed $>8 \mathrm{~g}$.
Among rats, 143 were females and 133 males, not significantly different from parity $\left(X^{2}=0.23, P=0.23\right)$. The mean weight of nonpregnant females $(n=126)$ of $65.5 \mathrm{~g}$ (SE $=2.6$ g) was not statistically different from the $72.2 \mathrm{~g}(\mathrm{SE}=3.1 \mathrm{~g})$ of males $(t=1.61, P=0.11)$. The mean weight of pregnant

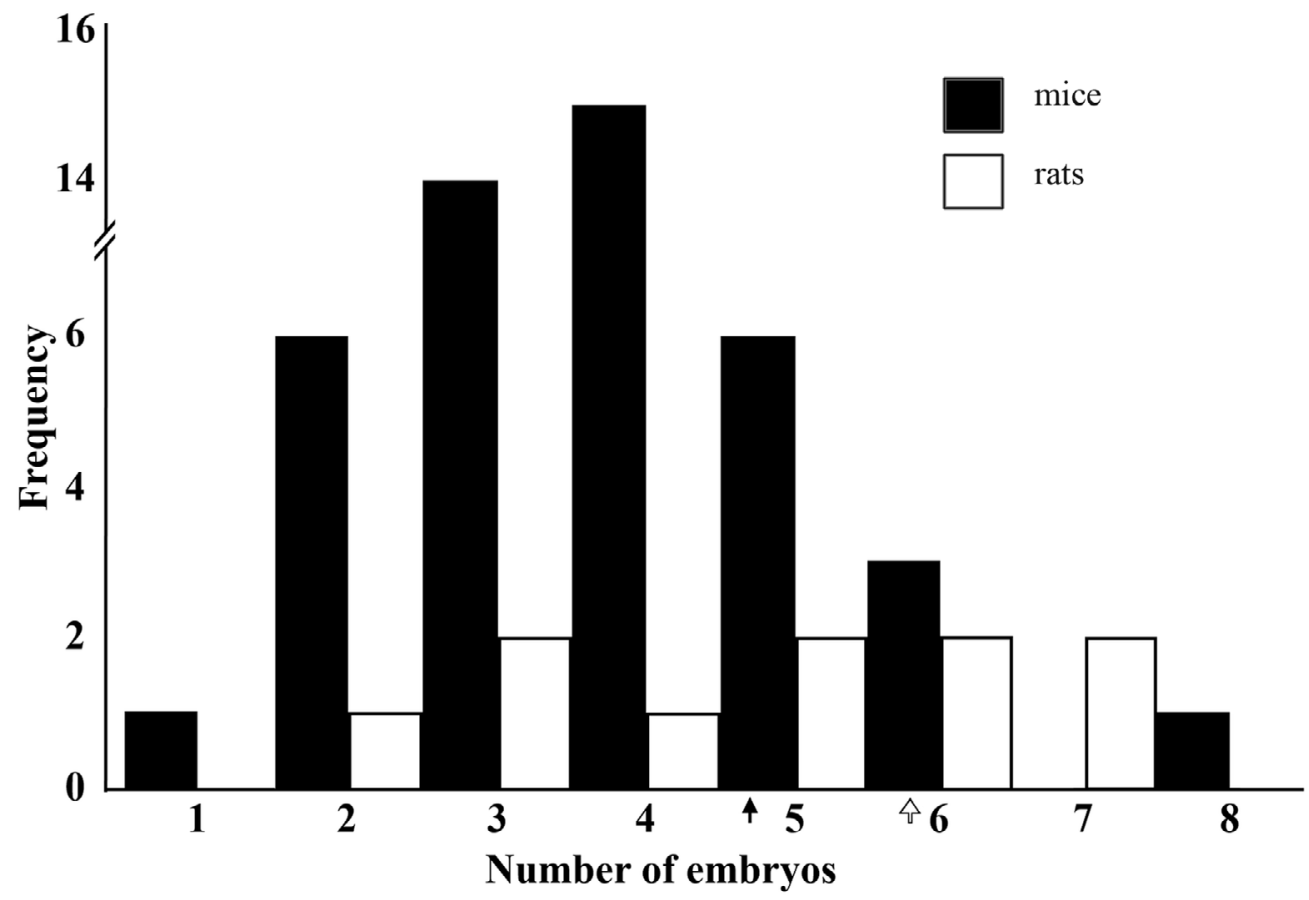

Figure 2. Distribution of embryos among female mice (Mus musculus) $(n=54)$ and rats (Rattus rattus) $(n=14)$. Black bars represent mice, white bars rats, and the arrows indicate the mean number embryos for mice and rats. 


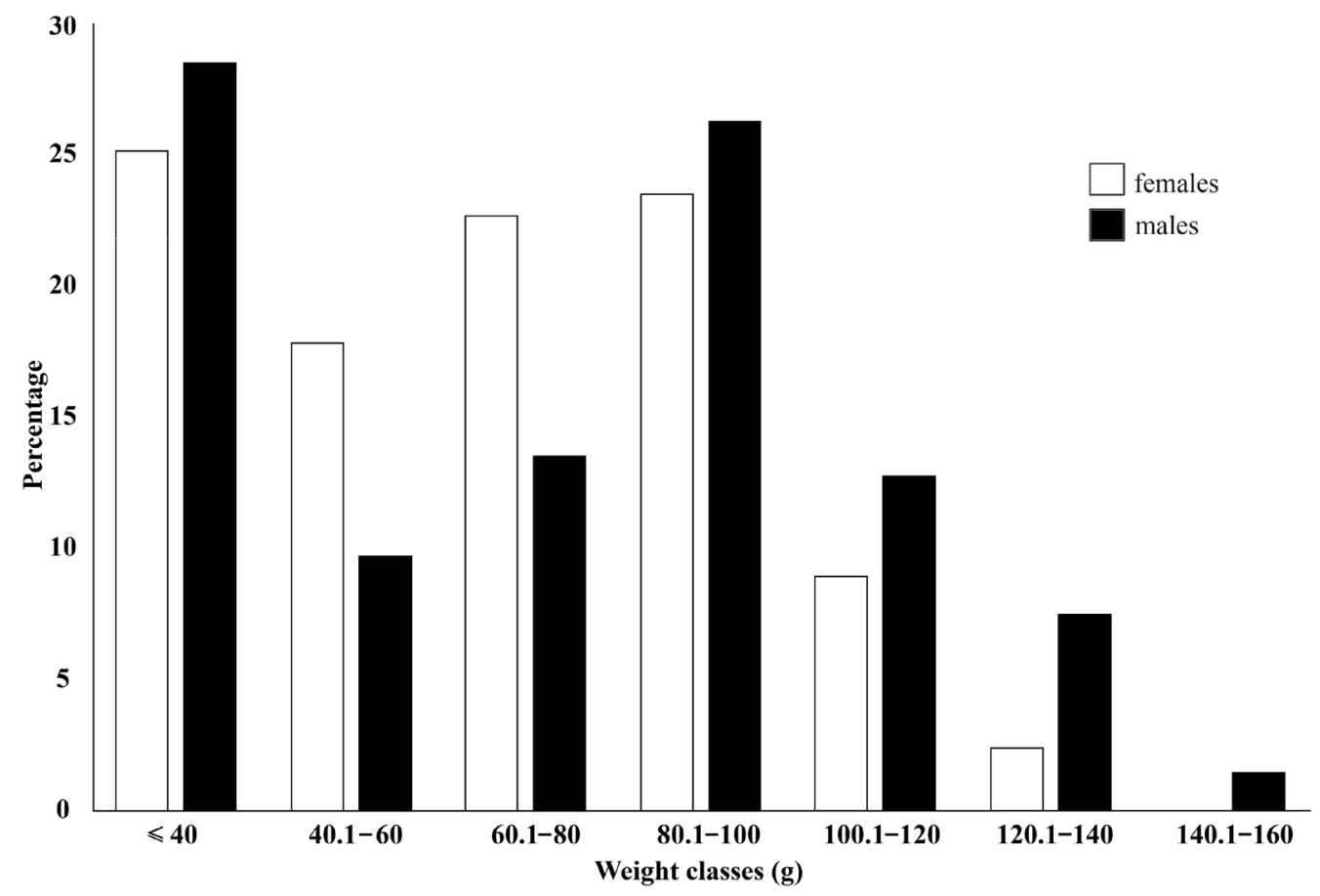

Figure 3. Comparison of weight classes for nonpregnant female $(n=126)$ and male $(n=133)$ black rats (Rattus rattus) from Mérida, Yucatán, México. White bars represent females and black bars males.

females was $103.3 \mathrm{~g}$ (SE $=4.4 \mathrm{~g})$. Rats in the weight class $\leq 40 \mathrm{~g}$ ( $25 \%$ of females and $28.6 \%$ of males) were most abundant. There was no significant difference in the weight structure between sexes $(D=0.13, P=0.18$; Figure 3). Maturity was recorded in $66.7 \%$ (86/129) of males and $56.7 \%$ (80/141) of females. Of mature females, 17 (21.3\%) were pregnant and 14 (17.5\%) lactating. The mean number of embryos per female was 5.8 (range $=3-8$; Figure 2 ). All pregnant or lactating females weighed $>66 \mathrm{~g}$.

\section{Discussion}

The adjustment of the sex ratio of offspring is a facultative capacity of polygynous species (Trivers and Willard, 1973). Laboratory studies have shown that maternal nutrition can affect the sex ratio and viability of litters (Rosenfeld and Roberts, 2004). In rodents, a sex ratio of $1: 1$ has been reported when food is nutritionally balanced and ad libitum, whereas under deficient or restricted diets females produce a male-biased sex ratio (Wright et al., 1988; Rosenfeld and Roberts, 2004). Field studies have shown that sex ratio can vary in relation to different habitats, seasons, or human disturbances that offer plentiful food resources (Smith, 1954; Brown, 1963; Gomez et al., 2008; Panti-May et al., 2012). Although the urban environment offers a moderately stable habitat for commensal rodents, the food supply in sampled households may not be superabundant or nutritionally balanced, favoring a male-biased sex ratio in mice. In contrast to house mice that eat any accessible human food, black rats preferentially consume fruits, seeds, and insects even in the presence of human food or garbage (Battersby et al., 2008; Feng and Himsworth, 2014), suggesting that rats could have an adequate diet. However, other factorssuch as juvenile mortality, inbreeding, or population density-could contribute to this result (Clutton-Brock and lason, 1986).

In this study, we found that Mérida rodents had high reproductive rates. In general, Mérida rodents showed similar reproductive characteristics to that of temperate rodents (Davis, 1947; Storer and Davis, 1953; Smith, 1954; Brown, 1963; Vadell et al., 2010). For instance, in Mississippi, USA, Smith (1954) reported in house mice a mean number of embryos of 4.8 and a percentage of pregnancy of $46.8 \%$. In San Francisco, USA, Storer and Davis (1953) found a mean number of embryos of 7.1 and a percentage of pregnancy of $20.4 \%$ in black rats. In contrast, Mérida rodents appear to be lighter than their temperate counterparts. In Maryland, USA, $28 \%$ of mice captured on a horse farm weighed $\leq 12 \mathrm{~g}$ (Brown, 1963), a greater difference compared to $>50 \%$ from our study. Heavy black rats (> $140 \mathrm{~g}$ ) were rarely trapped in Mérida (1\%), whereas in San Francisco they were abundant (35\%) (Storer and Davis, 1956). Some studies have shown that island house mice and urban Norway rats from tropical regions are smaller in size compared 
to those from temperate regions (Berry and Scriven, 2005; Porter et al., 2015). It has been suggested that this difference could be a result of an adaptive adjustment, particularly in the absence of predators (Berry and Scriven, 2005).

House mice and black rats live commensally with humans in a wide variety of habitats around the world (Berry, 1981). However, in Latin America, knowledge about the ecology of commensal populations is limited compared to what is understood in temperate regions (Smith, 1954; Brown, 1963; Gomez et al., 2008; Vadell et al., 2010; León et al., 2013). This study provides relevant demographic information for understanding the ecology of commensal rodents from a municipality located in a tropical region in Latin America. We consider that our findings could be useful as a first step toward understanding the ecological behavior of rodent populations in tropical regions.

Acknowledgments - This project was funded by PROMEPMéxico-Proyecto 103.5/09/1258 (Red epidemiológica de enfermedades zoonóticas y transmitidas por vectores de importancia en salud pública) and by FOMIX-CONACYT FOMIX-YUC-2008-108929 (Sensibilidad y vulnerabilidad de los ecosistemas costeros del sureste de México ante el Cambio Climático Global). We thank Josh Taylor for his valuable comments and revision of the English version, and to all Yucatecan families for their time and cooperation in getting the rodents.

\section{Literature Cited}

Battersby, S., R. B. Hirschhorn, and B. R. Amman. 2008. Commensal rodents. Pages 387-419. In: Public health significance of urban pests. Ed. by X. Bonnefoy, H. Kampen, and K. Sweeney. World Health Organization, Copenhagen.

Berry, R. J. 1981. Town mouse, country mouse: Adaptation and adaptability in Mus domesticus (M. musculus domesticus). Mammal Review 11: 91-136.

Berry, R. J., and P. N. Scriven. 2005. The house mouse: A model and motor for evolutionary understanding. Biological Journal of the Linnean Society 84: 335-347.

Brown, R. Z. 1963. Social behavior, reproduction, and population changes in the house mouse (Mus musculus L.). Ecological Monographs 23: 217-240.

Cigarroa-Toledo, N., L. G. Talavera-Aguilar, C. M. Baak-Baak, J. E. García-Rejón, S. Hernández-Betancourt, B. J. Blitvich, and C. Machain-Williams. 2016. Serologic evidence of flavivirus infections in peridomestic rodents in Merida, Mexico. Journal of Wildlife Diseases 52: 168-172.

Clapperton, B. K. 2006. A review of the current knowledge of rodent behavior in relation to control devices. Science for Conservation 263: 1-55.

Clutton-Brock, T. H., and G. R. lason. 1986. Sex ratio variation in mammals. Quarterly Review of Biology 61: 339-374.
Davis, D. E. 1947. Notes on commensal rats in Lavaca County Texas. Journal of Mammalogy 28: 241-244.

de Masi, E., P. Vilaça, and M. T. P. Razzolini. 2009. Environmental conditions and rodent infestation in Campo Limpo district, Sao Paulo municipality, Brazil. International Journal of Environmental Health Research 19: 1-16.

Feng, A. Y. T., and C. G. Himsworth. 2014. The secret life of the city rat: A review of the ecology of urban Norway and black rats (Rattus norvegicus and Rattus rattus). Urban Ecosystems 17: 149-162.

Gomez, M. D., J. Priotto, M. C. Provensal, A. Steinmann, E. Castillo, and J. J. Polop. 2008. A population study of house mice (Mus musculus) inhabiting different habitats in an Argentine urban area. International Biodeterioration \& Biodegradation 62: 270-273.

Instituto Nacional de Estadística y Geografía. 2010. Población total: Yucatán. México en cifras. Available at website: www. inegi.org.mx. Accessed 2 February 2016.

Instituto Nacional de Estadística y Geografía. 2015. Climatología. Available at website: www.inegi.org.mx. Accessed 19 April 2015.

Langton, S. D., D. P. Cowan, and A. N. Meyer. 2001. The occurrence of commensal rodents in dwellings as revealed by the 1996 English House Condition Survey. Journal of Applied Ecology 38: 699-709.

Leary, S., W. Underwood, E. Lilly, R. Anthony, S. Cartner, D. Corey, T. Grandin, C. Greenacre, F. Collins, C. Greenacre, S. Gwaltney-Brant, M. A. McCrackin, R. Meyer, M. State, D. Miller, J. Shearer and R. Yanong. 2013. AVMA guidelines for the euthanasia of animals: 2013 Edition. American Veterinary Medical Association, Schaumburg, Illinois.

León, V. A., J. Fraschina, J. S. Guidobono, and M. Busch. 2013. Habitat use and demography of Mus musculus in a rural landscape of Argentina. Integrative Zoology S1: 18-29.

Panti-May, J. A., S. F. Hernández-Betancourt, H. Ruiz-Piña, and S. Medina-Peralta. 2012. Abundance and population parameters of commensal rodents present in rural households in Yucatan, Mexico. International Biodeterioration \& Biodegradation 66: 77-81.

Panti-May, J. A., S. F. Hernández-Betancourt, R. I. RodríguezVivas, and M. R. Robles. 2015. Infection levels of intestinal helminths in two commensal rodent species from rural households in Yucatan, Mexico. Journal of Helminthology 89: 42-48.

Porter, F. H., F. Costa, G. Rodrigues, H. Farias, M. Cunha, G. E. Glass, M. G. Reis, A. I. Ko, and J. E. Childs. 2015. Morphometric and demographic differences between tropical and temperate Norway rats (Rattus norvegicus). Journal of Mammalogy 96: 317-323.

Rosenfeld, C. S., and R. M. Roberts. 2004. Maternal diet and other factors affecting offspring sex ratio: A review. Biology of Reproduction 71: 1063-1070.

Secretaría de Agricultura, Ganadería, Desarrollo Rural, Pesca y Alimentación, SAGARPA. 1999. NOM-062-ZOO-1999. Especificaciones técnicas para la producción, cuidado y uso 
de los animales de laboratorio. NOM-062-ZOO-1999. Diario Oficial de la Federación, México.

Sheskin, D. J. 2004. Handbook of parametric and nonparametric statistical procedures. 3rd ed. Chapman \& Hall/CRC, Boca Raton, Florida.

Sikes, R. S., W. L. Gannon, and Animal Care and Use Committee of the American Society of Mammalogists. 2011. Guidelines of the American Society of Mammalogists for the use of wild mammals in research. Journal of Mammalogy 92: 235-253.

Smith, W. W. 1954. Reproduction in the house mouse, Mus musculus L., in Mississippi. Journal of Mammalogy 35: 509-515.

Storer, T. I., and D. E. Davis. 1953. Studies on rat reproduction in San Francisco. Journal of Mammalogy 34: 365-373.

Torres-Castro, M. A., E. Gutiérrez-Ruiz, S. F. Hernández-Betancourt, R. Peláez-Sánchez, P. Agudelo-Flórez, L. Guillermo-Cordero, and F. I. Puerto. 2014. First molecular evidence of Leptospira spp. in synanthropic rodents captured in Yucatan, Mexico. Revue de Médecine Vétérinaire 7-8: 213-218.
Trivers, R. L., and D. E. Willard. 1973. Natural selection of parental ability to vary the sex ratio of offspring. Science 179: 90-92.

Vadell, M. V, I. E. Gómez Villafañe, and R. Cavia. 2014. Are lifehistory strategies of Norway rats (Rattus norvegicus) and house mice (Mus musculus) dependent on environmental characteristics? Wildlife Research 41: 172-184.

Vadell, M. V., R. Cavia, and O. V. Suárez. 2010. Abundance, age structure, and reproductive patterns of Rattus norvegicus and Mus musculus in two areas of the city of Buenos Aires. International Journal of Pest Management 56: 327-336.

Wright, S. L., C. B. Crawford, and J. L. Anderson. 1988. Allocation of reproductive effort in Mus domesticus: responses of offspring sex ratio and quality to social density and food availability. Behavioral Ecology and Sociobiology 23: 357-365.

Zar, J. 1996. Biostatistical Analysis. Prentice Hall, Englewood Cliffs, New Jersey. 